\title{
フレッシュコンクリート中の自由水の挙動と 透水・脱水メカニズム
}

\author{
犬飼 利嗣*1 $・$ 三島 直生 ${ }^{* 2} \cdot$ 畑中 重光*3
}

\begin{abstract}
概 要一般的に用いられるコンクリートでは，施工上の要求から，余剩水（自由水）を含む一定の水量が必要となる。 したがって，フレッシュコンクリート中の自由水の挙動を把握することは，材料分離現象や鉄筋コンクリート構造体の品 質を評価する上で, また, 透水型枠工法, 加圧脱水工法, 真空脱水工法など自由水の低減を目的とした工法では, そのメ カニズムを解明する上できわめて重要であるといえる。本稿では，ブリーディングによる自由水の挙動，ならびに透水型 枠工法, 加圧脱水工法, および真空脱水工法の脱水メカニズムに関するいくつかの知見を可視化実験を中心に紹介する。 キーワード：ブリーディング，自由水，可視化，透水型枠，加圧脱水，真空脱水，透水係数
\end{abstract}

\section{1. はじめに}

従来から一般的に用いられるコンクリートでは，十分 なワーカビリティーを得るという施工上の要求から，あ る一定の単位水量を必要としている。それは水セメント 比にすると，概ね 50〜60\%に相当する。しかし，これ までの研究や超高強度コンクリートの製造実績からも明 らかなように，セメントの水和反応に必要な水量は，水 セメント比にして $25 \%$ 程度である。すなわち，フレッ シュコンクリート中の自由水は施工上は必要な水である が，施工終了後は鉄筋コンクリート構造体に品質の低下 をあたらす余剰水となる。したがって，フレッシュコン クリート中の自由水の挙動を把握することは, コンクリー トの材料分離現象や鉄筋コンクリート構造体の品質を評 価する上で，きわめて重要であるといえる。

ブリーディングに関する研究は，これまでに数多く行 われてきた。しかし，自由水そのものの挙動に関する研

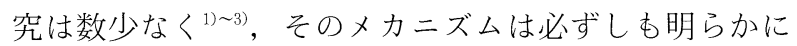
されていない。また, 透水型枠工法, 加圧脱水工法抢よ び真空脱水工法など，自由水の制御を目的とした工法 （図-1）では，そのメカニズムを解明する上で自由水の 挙動を知ることが不可欠である。さらには, 自由水の挙 動を制御するための新たな手法を見出す上でも役立つも のと考えられる。

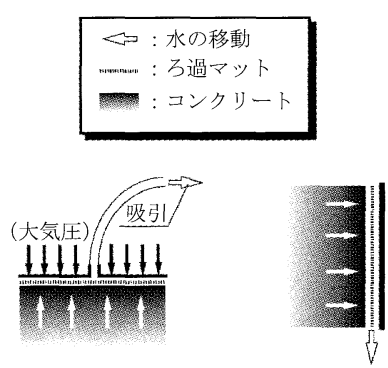

（a）真空脱水 $\quad$ (b) 透水型枠

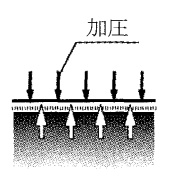

(c) 加圧脱水

（d）遠心脱水

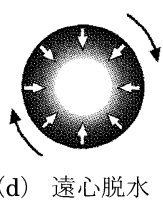

図-1 透水・脱水工法の概念

本稿では, ブリーディングによる自由水の挙動と, 透 水型枠工法, 加圧脱水工法, および真空脱水工法などと いった自由水の制御工法の脱水メカニズムを可視化実験 結果を中心に概説する。なお，ここでは，フレッシュコ ンクリート中の水に関する用語を表-1に示すように分 類・定義する。

2. フレッシュコンクリート中の自由水の挙動

2.1 着色液による自由水の可視化

着色液をモルタル中に注入（図-2）し，硬化後の側面

表-1 フレッシュコンクリート中の水の分類 ${ }^{4}$

\begin{tabular}{|c|c|c|}
\hline & 種 類 & 定 義 \\
\hline \multirow{4}{*}{$\begin{array}{l}\text { 練 } \\
\text { 皆 } \\
\text { 水 }\end{array}$} & 拘束水 & セメントと水和した結合水および固体粒子表面の吸着水 \\
\hline & 自由水 & 固体粒子から遊離して移動可能な拘束水以外の練混ぜ水 \\
\hline & (外部) ブリーディング水 & 固体粒子の自重沈降により上昇する自由水の一部で，コンクリート上面（または側面）まで到達した水 \\
\hline & 内部ブリーディング水 & 固体粒子の自重沈降により上昇する自由水の一部で, コンクリート内部に滞留した水 \\
\hline
\end{tabular}

*1 いぬかい・としつぐ/東海コンクリート工業(株) 企画・技術部 技術グループ 係長（正会員）

*2 みしま・なおき /三重大学大学院 工学研究科 建築学専攻 助教 (正会員)

＊3はななか・しげみつ/三重大学大学院 工学研究科 建築学専攻 教授 (正会員) 


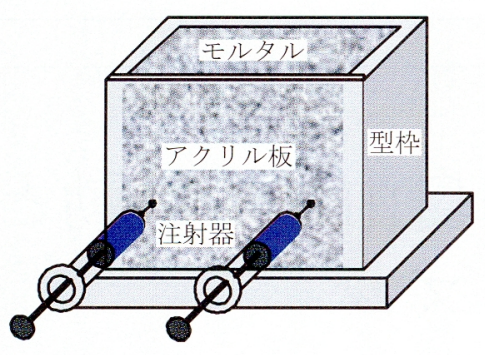

図-2 着色液の注入方法
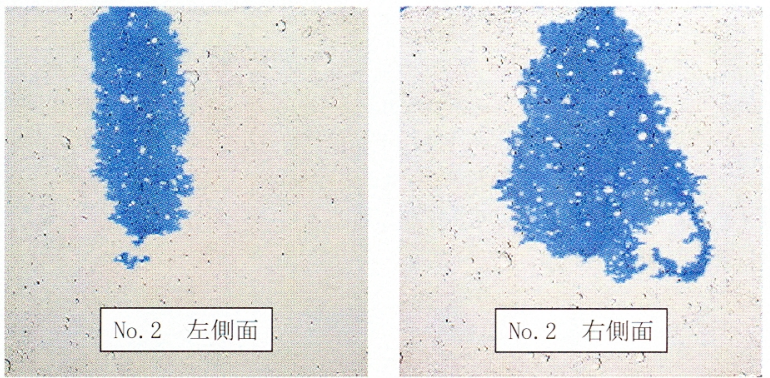

写真-1 側面の着色状態

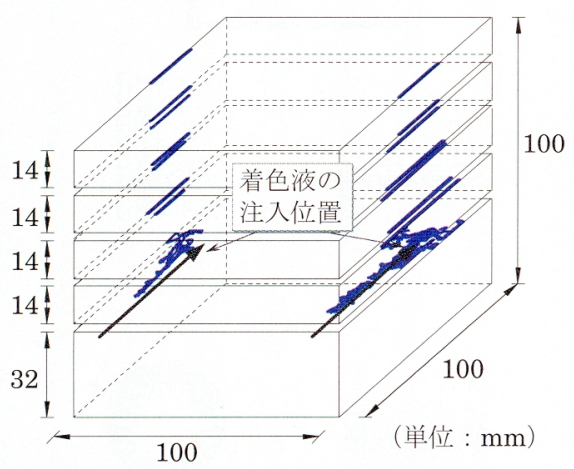

図-3＼cjkstart各切断面に分布した着色液（実験 No.2）

（写真-1）や切断面に分布した着色液（図-3）加ら，自 由水の挙動（水みち）を視覚的に評価することを試み だ。そして一連の実験（実験No.1～8）功，着色液 の注入位置, 打込み方法, 㧍よび締固め方法が，自由水 の挙動に及ぼす影響について検討した。

一例として，モルタル側面の着色状態を写真-1に， 水平切断面の着色状態を写真-2 に示す。試験時の観察 状況を含めて考察すると, 写真-1に示すように, 着色

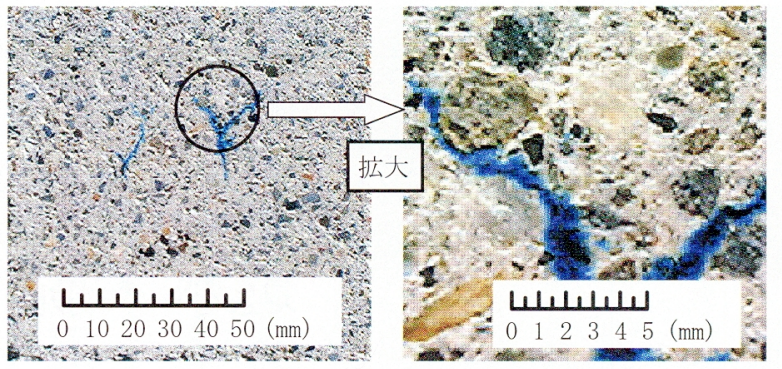

(a) No.3 (切断位置: 底面加 $534 \mathrm{~mm}$ )

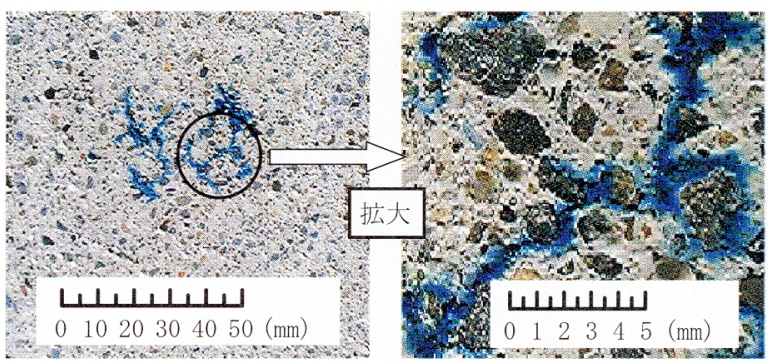

(b) No.4 (切断位置: 底面加ら $66 \mathrm{~mm}$ )

写真-2 水平切断面の着色状態

液が型枠の側面に到達した場合は，写真-2に示すよう な内部老上昇するものと比較して, 上昇速度が非常に速 くなる傾向にある。また，内部老上昇する着色液の多く は写真-2に示すように，細骨材粒子の表面を沿うよう に上昇している。したがって, 内部の自由水の多くは, セメントペーストと細骨材の界面を水みちとして上昇す るものと推察される。

硬化したモルタル内部の着色液の分布状況を図-4に 示す。着色液の存在領域は, 着色液の注入面(図-3の 前面）への投影図として表してある。いずれのモルタル においても, 着色液は注入位置から周囲に拡散すること はなく，すべて上昇している。したがって着色液の挙動 は，これと等量の自由水の挙動をほぼ再現していると判 断できる。つぎに, 着色液の注入位置による影響に着目 すると，（a）（d）の投影図に示すように，型枠側面か らの距離による影響が大きく，側面付近に注入した（a), （b）では，着色液が型枠面に沿って上昇している。こ れは, 既往の研究結果 ${ }^{1,5)}$ 上一致しており, 型枠面屯水 みちになることを示している。一方，打込み方法につい

Study on Free Water Behavior in Fresh Concrete and Dewatered Concrete By T. Inukai, N. Mishima and S. Hatanaka

Concrete Journal, Vol.45, No.3, pp.15 22, Mar. 2007

Synopsis Fresh concrete generally contains bleeding water (free water) which is considered to deteriorate the quality of reinforced concrete structures. Therefore, it is very important to clarify the behavior of free water in evaluating the behavior of bleeding and segregation, and the quality of reinforced concrete structures. Main purpose of the present study is to examine the behavior of free water in fresh concrete and in various kinds of dewatered concrete. In this report, the behavior of free water in bleeding and the dewatered mechanism are discussed, based on series of newly proposed visualization tests on the permeable form dewatering, press dewatering and vacuum processing methods as well as the bleeding.

Keywords : bleeding, free water, visualization, permeable form, press dewatering, vacuum processing, permeability coefficient 
ては，1層詰めとした（c）扔よび（d）と，２層詰めと した（e）および（f）との比較によれば，打重ねによる
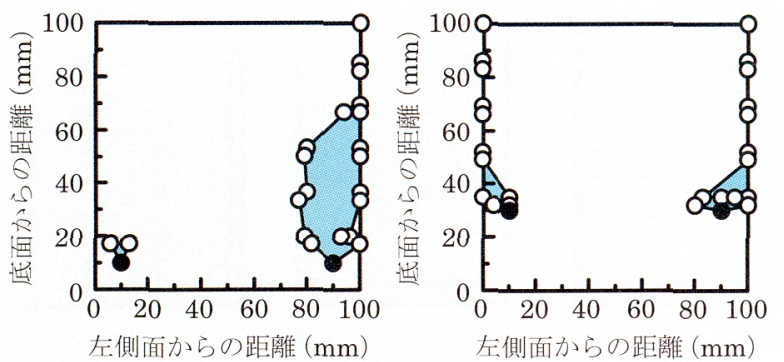

(a) No.1 (1 層詰め, 突き固め法)

(b) No.2(1 層詰め, 突き固め法)
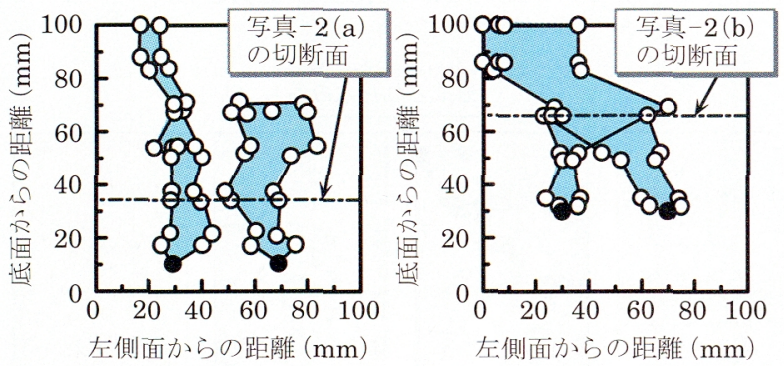

(c) No.3 (1 層詰め, 突き固め法)
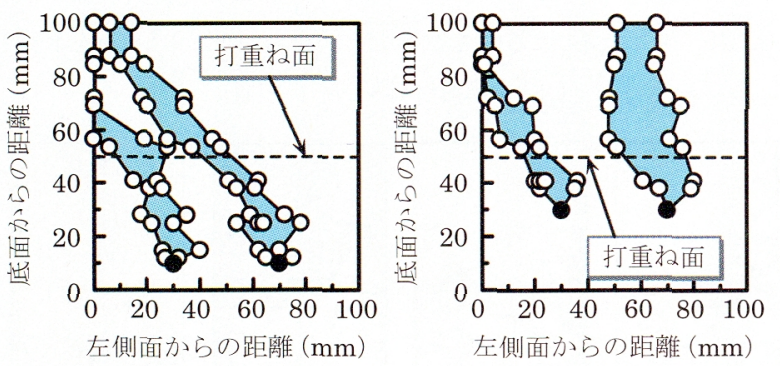

(e) No.5 (2 層詰め, 突き固め法) (f) No.6 (2 層詰め, 突き固め法)
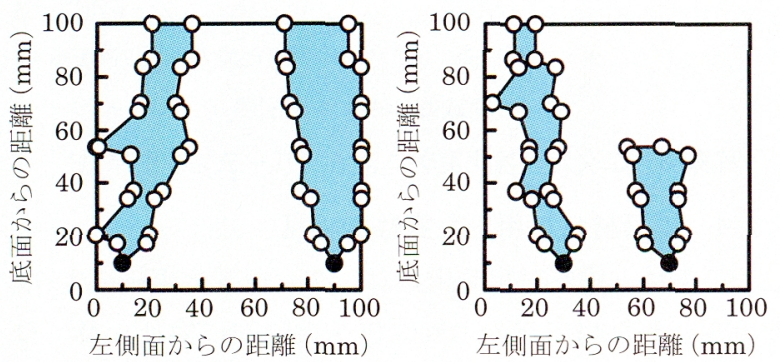

(g) No.7(1 層詰め), 振動締固め法)

(h) No.8(1層詰め, 振動締固め法)

は，着色液の注入位置を示す)

図-4 着色液の分布（着色液の注入面に投影した着色液の 存在領域 $)^{4}$

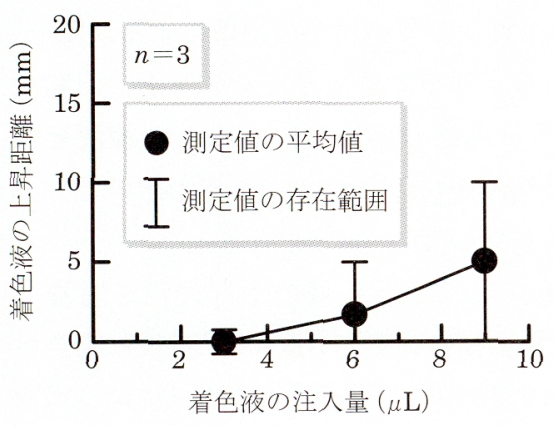

(a) 水セメント比 $35 \%$

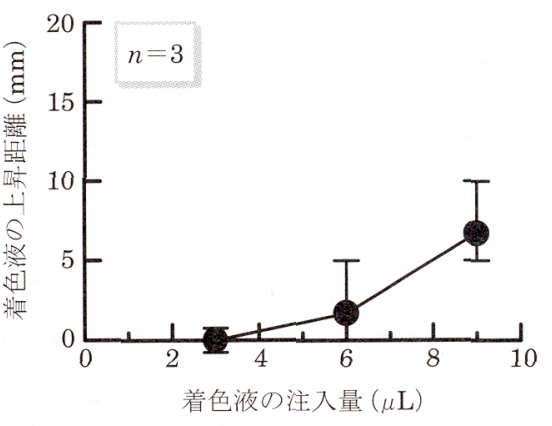

(b) 水セメント比 $50 \%$
影響はみられない。これは, 既往の研究結果 ${ }^{1}$ 上異なる 結果である。また，テーブルバイブレータによる振動締 固めの影響について調べた（g）および（h）では，着 色液は側面に到達するすのの型枠に沿ってそのまま上昇 するわけではない。これは, テーブルバイブレータで振 動されたモルタルの対流によって形成された水タちの影 響が現れた結果と判断された。

\section{2 自由水の上昇距離}

着色液による視覚的評価方法により, モルタル中の自 由水の挙動を擬似的に確認することにした。そこで，自 由水の挙動を定量的に把握するために, 水セメント比抢 よび着色液の注入量が，その上昇距離に及ぼす影響につ いて検討した。

着色液をモルタル中に注入し, 硬化後に切断した水平 切断面の着色状態を観察して, 注入位置から上昇した着 色液の上昇距離を测定した（図-5）。水セメント比ごと に整理すると, 着色液の上昇距離と注入量の関係は図-6 のようになる。図に示すように，水セメント比が大きく なると, 着色液の上昇距離は長くなる傾向を示している。 また同様に, 着色液の注入量が多くなると, 上昇距離む 長くなる傾向にある。

水セメント比 $65 \%$ のルタルでは, 着色液の上昇距 離が極端に長く, 一部の試験体では着色液を $9 \mu \mathrm{L}$ 注入 すると，その上昇距離は試験体の上面（上昇距離が 95 $\mathrm{m} m$ 以上）まで達した。着色液が上面に到達すると，

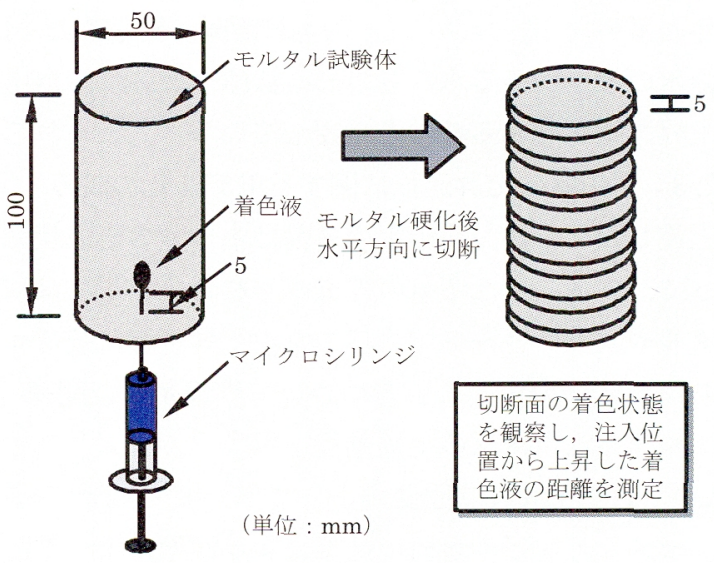

図-5 着色液の注入量方法

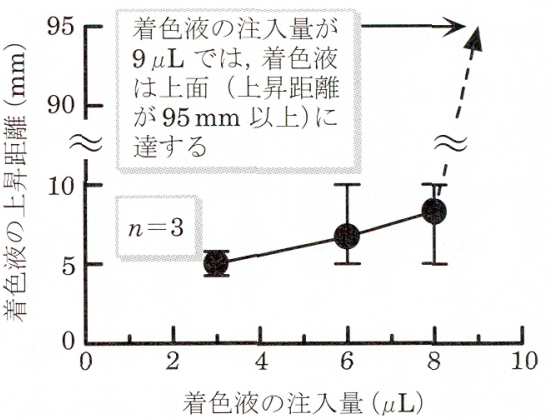

(c) 水セメント比 $65 \%$

図-6 着色液の上昇距離と注入量の関係 


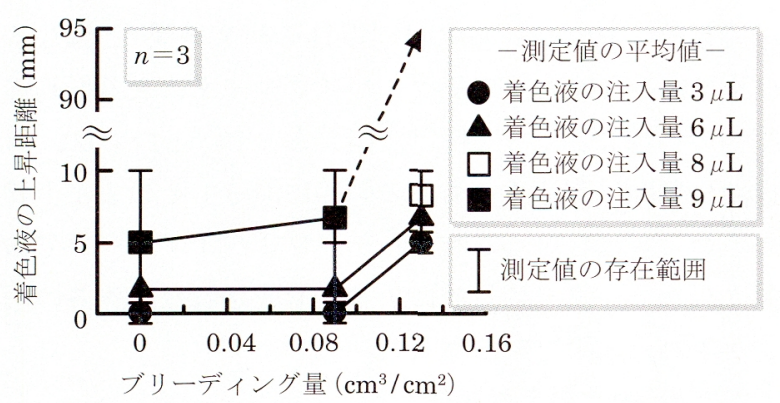

図-7 着色液の上昇距離とブリーディング量の関係

上昇距離を定量的汇評価できないので, 水セメント比 $65 \%$ のルタルのみ，実験水準として $8 \mu \mathrm{L}$ の注入量を 追加した。水セメント比 $35 \%$ 之 $50 \%$ のモルタルを比較 してみると, 着色液の注入量が $3 \sim 6 \mu \mathrm{L}$ の範囲では上昇 距離に差はみら机ないが，注入量が $9 \mu \mathrm{L}$ になると水也 メント比 50\% のモルタルは, $35 \%$ のモルタル之比較し て上昇距離が若干長くなる傾向にある。

図-7は，着色液の上昇距離上外部ブリーディング水 量（ブリーディング量）の関係を示したものである。図 に上机ば，両者の関係には必ずしも明確な相関がある上 はいえないが，外部ブリーディング水量が多くなると着 色液の上昇距離屯長くなる傾向がみられる。

このように, 着色液の上昇距離にはモル夕ルの水セメ ント比だけではなく注入量による影響がみられ，実際の 自由水の挙動を定量的に評価することは容易ではない。 しかし, 着色液に上って, 自由水の上昇挙動を定性的に は確認できることが示唆されたといえる。また，着色液 の注入量が同一であっても乞の上昇距離が異なるこ上は, 自由水の近傍にある水及ちの形成状態によって, 自由水 の上昇距離が異なることを示唆していると考えられる。

\section{3 自由水の上昇過程に関するモデル化の試み}

上述したように, 自由水の挙動は水みちの形成状態に よって，大きく異なるものと推察された。ここでは，モ ルタルやコンクリート中の自由水の上昇過程に及ぼす水 みち，抢よび型枠面の影響について整理する。図-8に， モデル化した自由水の上昇過程を示す。

（a）は，自由水の近傍にある試料が均一な状態を示 す。セメント粒子や骨材の沈降による置換によって, 自 由水はゆっくり上昇していく。この場合，自由水の上昇 速度は小さくその距離む短いが, 調合や材料に上る影響 は比較的大きい。

（b）は，何らかの原因により試料が不均一となり， 自由水の近傍に水みちが形成されている状態を示す。こ の場合，自由水の上昇速度は大きくその距離も長くなる が，調合や材料による影響は比較的小さい。

（c）は，自由水の近傍に型枠面があり，壁効果によっ て型枠面が水みちとなっている状態を示す。この場合, （b）上同様で，自由水の上昇速度は大きくその距離む 長くなり，調合や材料による影響は比較的小さい。

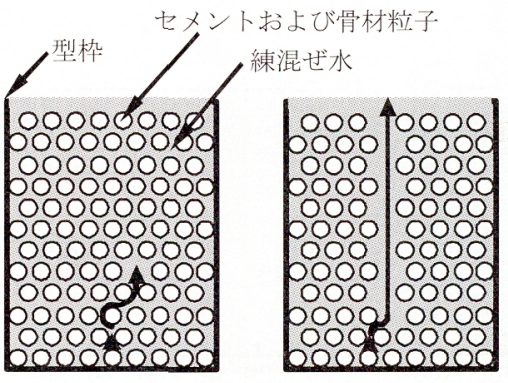

(a) 試料が均一な 場合 (b) 試料に水多ちが 女る場合

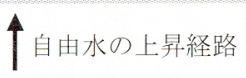

A自由水の発生位置

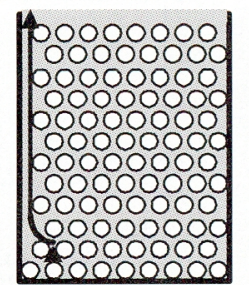

c) 型枠側面が水攵ち になる場合
図-8 モデル化した自由水の上昇過程

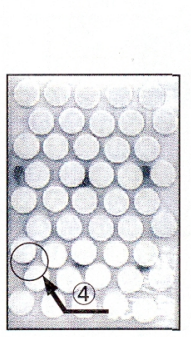

(a) 実験開始直後

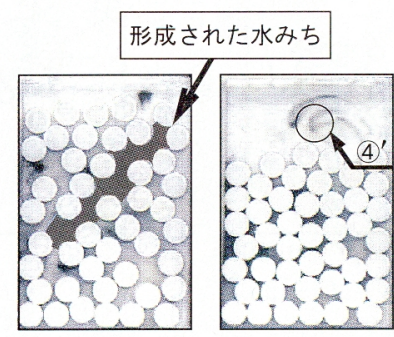

(b) 8 秒後

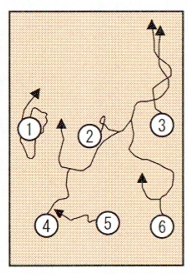

（d）着色液の軌跡 [(a）（4)，(4)'は上昇した着色液，(d）(1)～6 は着色液の注入位置圭示す]

(1) 模擬材料を均一に配置

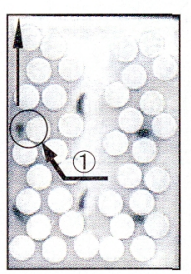

(a) 実験開始直捘

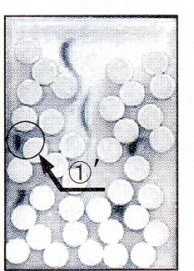

(b) 3 秒後

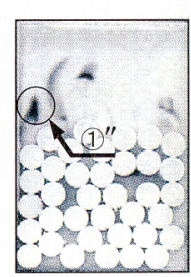

(c) 40 秒後

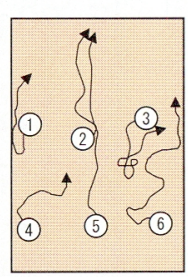

（d）着色液の軌趾 [(a) (1)〜 (1)"は上昇した着色液，（d）(1)（6)は着色液の注入位置を示す

(2) 模式的に水みち死配置

写真-3 二次元可視化実験によるブリーディング挙動

\section{4 模擬材料を用いた実験的検証}

ここでは，模擬材料を用いた二次元可視化実験により， モデル化した自由水の上昇過程を実験的に検証した。七 メント抢よび骨材などの固体粒子には，ポリアセタール 樹脂製の川柱体を，練混ぜ水とした模擬水には，セルロー 又采増粘剂の水溶液在用いた。また, 自由水の挙動を観 察するマーカとして，模擬水にアクリル塗料圭混合した 着色液を用いた。なお，二次元可視化実験で対象として いるのは，セメント抢よび骨材粒子の自重による沈降と， それに伴う間隙水の上昇挙動であり，セメントの水和や 凝集による影響 とした模擬水には粘性を付与したので，自由水の上萛速 度も評価の刘象としていない。

固体粒子の沈降, および着色液の上昇過程を写真-3 （1）（2）に示す。模擬材料を均一に配置した場合は 写真-3（1）に示术うに，固体粒子の沈降に伴う緻密 化は下層から始まり, 中央部の中層および下層に注入し た着色液は，固体粒子に置換されゆっくり上昇している。 
一方, 下層左側に注入した着色液(4)は, 固体粒子の不規 則な沈降によって形成された水みちに沿って，上層(4) まで到達している。

模式的に中央部に水みちを配置した場合も写真-3（2） に示すように, 固体粒子の沈降に伴う充てんは下層から ゆっくり始まるが，中央部の水みち付近に注入した着色 液(2)，(5)は，実験開始直後より速やかに上昇している。 その上昇速度は, 固体粒子の層間に注入した他の着色液 と比較して，明らかに大きくなっている。また，写真-3 （2）中の(1)〜 (3)に示すように，中層左側に注入した着 色液(1)は, 容器側面に沿って上昇している。なお, 模式 的に配置した水みちは，写真-3（2）に示した（b)， (c) からわかるように，固体粒子によって充てんされ， 同時に模擬水の上昇を促している。

このように, 固体粒子の沈降および着色液の上昇過程 は，モデル化した自由水の上昇過程とほぼ一致した結果 を示している。着色液を用いた可視化実験結果も踏まえ れば，モルタルやコンクリート内部における自由水の挙 動を定量的に把握するためには, 型枠などの境界効果お よび打込み後に形成される水みちの影響をむ含めて，ブ リーディング現象のモデル化を行う必要があるといえる。

3. 透水・脱水メカニズム

\section{1 透水・脱水工法の概要と特徵}

ここでは, 文献 8）より, 各種透水・脱水工法の概要 と特徵について紹介する。

（1）透水型枠工法

透水性を有する識布または不識布, 微細な小孔を配し たフィルムシート, 吸水性ポリマーを含むシートなどの 透水型枠用シートを型枠のせき板に取り付け，女き板近 傍のコンクリート中の余剩水や気泡を型枠外に排出させ る工法を指す。または，せき板に設けた微細孔や鋼製型 枠のスキンプレート部に設けた透水性を有するスリット 孔より排水・排気させる機能を持たせた型枠を使用する 工法ともいえる。コンクリート中の余剩水や空気は，コ ンクリートの自重により間隙水圧が上昇することによっ て排出されるため, 効率のよい排水効果を得るには部材 の高さを確保する必要性があること, 部材下部ではセメ ント粒子の表面析出によりコンクリート表面が黒っぽく なる現象が生じるこよが指摘されている。

（2）吸水シート工法

吸水能力を持つ超吸収性繊維を打設直後のコンクリー 卜表面に敷設したり，型枠面に吸水性を有するシートを 設置して，フレッシュコンクリートの余剰水や気泡を減 少させ, コンクリート硬化後の表面強度や緻密さ, 仕上 がりの向上を図るあのである。吸水メカニズムは，基本 的には吸水材料の吸水膨潤力と毛細管圧を利用してコン クリート中の余剩水を吸収し，気泡を排出するものであ る。さらに，吸水材料の持つ保水性を利用して，これを
コンクリート面に残置することによってコンクリートの 初期養生に役立たせるあのである。

(3) 真空脱水工法

大気圧を利用した締固め効果（真空減圧による加圧） によってコンクリート中の余剩水が排出されるこよによ り品質が改善されるむので, コンクリート床スラブのよ うに表面に不可避の弱化層が生じる場合に用いられる。 これまでの研究では, 余剰水の脱水メカニズムに関して の研究例は少なく, 真空脱水処理されたコンクリートの 品質 (圧縮強度, 耐久性等) に関する研究例が多くみら れる。

（4）遠心力締固め工法

コンクリートを入れた円筒形の型枠を用いて回転させ， 回転によって生じる遠心力によってコンクリートを中空 円管に成形するあのである。遠心力締固め工法が中空円 管製品を非常に効率よく成形できること, 成形の過程に おいてコンクリートから脱水が行われ， $60 \sim 85 \mathrm{~N} / \mathrm{mm}^{2}$ の高強度コンクリートが比較的容易に得られることなど から，国内に扮いてはコンクリートポール，パイル扰よ びヒューム管のほとんどがこの方法によって製造されて いる。

（5）加圧脱水工法

コンクリートを加圧することによって強制的にコンク リート中の余剰水を排出させることにより品質を改善す るあのである。これまでの研究例は，脱水処理されたコ ンクリートの圧縮強度の増加や気泡の抑制効果等に関す るものがほとんどで, 余剰水の脱水メカニズムについて の研究例は少ない。

（6）再振動締固め工法

コンクリートの打込みが終了し，しばらくしてから再 振動を与えることでコンクリートの品質改善を行う方法 である。コンクリートの打設面に生ずる微細なひび割れ （プラスチックひび割れ）の発生を低減させたり，打継 ぎ部の付着強度の改善を目的に行われるが，その夕イミ ングが難しい。早すぎると効果が小さく, 遅すぎるとコ ンクリートの締め固めができずに内部に穴や緩みを残す ことになり，逆効果を招くことになる。再振動に適当な 時期は，外気温や使用材料，配（調）合などによってあ る程度の幅はあるが，一般にブリーディングが終了する 前までとするのがよいとされている。

\section{2 透水・脱水による自由水の挙動}

各種の透水・脱水工法より, 透水型枠工法, 加圧脱水 工法, および真空脱水工法を取り上げ，自由水の挙動を 解明することを目的として，2.4 節に引き続き模擬材料 を用いた二次元可視化実験を行った ${ }^{9)}$ 。

（1）透水型枠工法

写真-4に, 透水型枠工法による二次元可視化実験の 状況を示す。（a）に示すように立て起こした直後は， 固体粒子が規則正しく並んでいる。排水開始後, 間もな 
くすると排水孔のある容器側面の近傍に注入した着色液 は, 容器の外側に流出している。また，（c）に示すよう に排水孔のある容器側面では, 固体粒子の充てんにより 排水孔が詰まり, 排水孔より高い位置に液面があるに屯 かかわらず排水が終了している。(d) に, 着色液の軌 跡を示す（1)～(9)または(12)は着色液の注入位置，个は着 色液の軌跡孝示す)。(d）に示すように，容器側面近傍 に注入した着色液（3)，(6，9，(12）は，すべて排水孔 に向かって移動している。また固体粒子の沈降に伴い,

(1)，(5)，(8)，(11)位置に注入した着色液は，下方に移動 している。これは，写真-3（1）（d），および（2）(d) に示したようなブリーディングによる二次元可視化実 験》ではみられない挙動であるが，コンクリートで可視 化実験を行った既往の研究結果 ${ }^{10)}$ 上ほぼ一致しており, 側面からの排水の影響がブリーディング（固体粒子の沈 降に伴う自由水の上昇）挙動上り卓越したもの上考えら れる。

このように，透水型染工法による排水では，ブリーディ ング現象や他の脱水工法之異なり，自由水之固体粒子が 同一方向に移動することに特徵がある。また自由水の排 出は，透水面にセメント粒子や骨材粒子が充てんされ終 〕する。

（2）加圧脱水工法

写真-5に, 加压脱水工法に上万次元可視化実験の 状況を示す。(a)〜 (c) に示すように，固体粒子は上層 加ら充てんされ，そ机化伴い着色液も上層加ら順に移動 して排水されている。一方，下層の固体粒子扔上び着色 液には，ほとんど移動はみられない。また（c）に示す 上うに，加圧を続けると上層の固体粒子が詰まり，排水 することが不可能となった。同様な実験結果は, 繰返し 観察された。（d）に，着色液の軌跡を示す。(d) に示 すように，上層に注入した着色液ほど移動距離が長くなっ ている。

このように，コンクリート中の自由水は，加圧脱水に より，セメント粒子や骨材粒子が上層から順に圧密され るにともない，上層加ら順に移動して排出される。これ らの結果は, 加圧脱水による圧密効果がコンクリートの 全層で，ほぼ同じであるという報告"11)之は異なるが，こ れは本実験を二次元のもとで行った（固体粒子を円柱体 とした）ことで，上層部に閉塞が生じたことが原因と考 えられる。しかし，実際のモルタルやコンクリートでむ， これほど顕著ではないが，固体粒子の粒度分布や粒子形 状，または体積割合によっては同様の傾向が生じると推 察される。

(3) 真空脱水工法

写真-6に, 真空脱水工法に上る二次元可視化実験の 状沉を示す。(a)～(c) に示すように，固体粒子は上層 加ら充てんされ，それに伴い着色液も上層加脱水され ている。一方，下層の固体粒子扔上び着色液には移動は

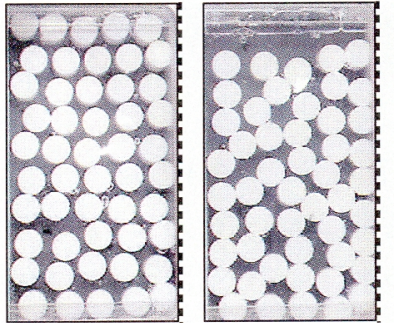

（a）実験開始直後 (b) 6 秒後

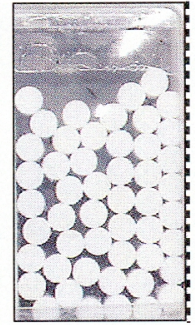

(c) 40 秒後

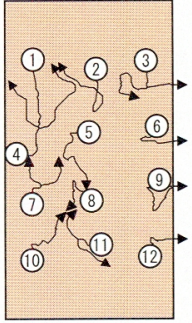

（d）着色液の軌跡
写真-4 透水型枠工法による二次元可視化実験状況 (--.- は排水面を示す $)^{9)}$

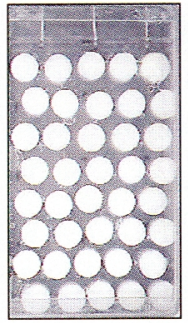

(a) 実験開始直後

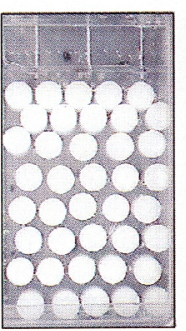

(b) 10 秒後

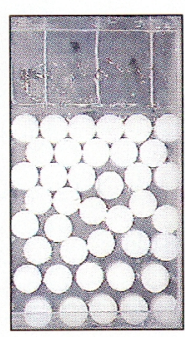

(c) 40 秒後

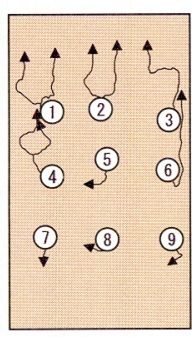

（d）着色液の軌跡
写真-5 加圧脱水工法による二次元可視化実験状況

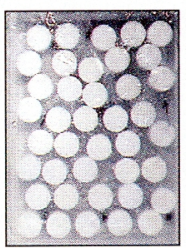

(a) 実験開始直後

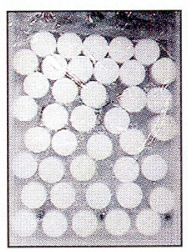

(b) 10 秒後

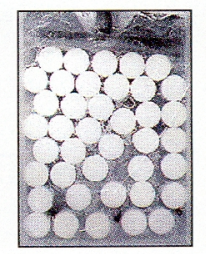

(c) 40 秒後

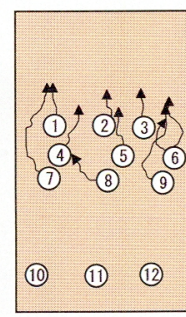

（d）着色液の軌趾
写真-6 真空脱水工法による二次元可視化実験状況 9
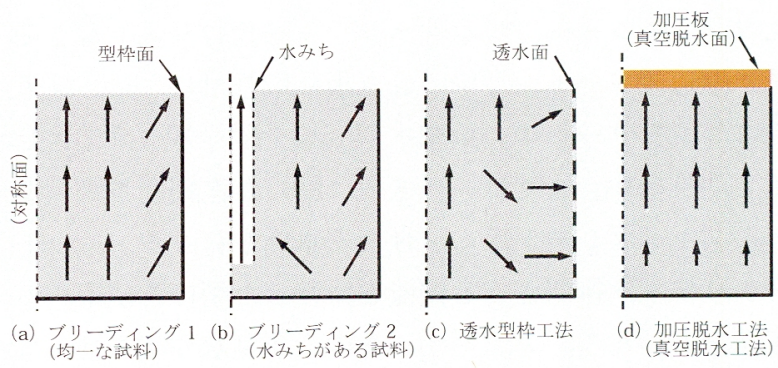

図-9＼cjkstart模式的に表した自由水の移動状況

みられない。また（c）に示すように，真空脱水を続け ると加圧脱水工法之同様に，上層の固体粒子が詰まって 脱水することが不可能となった。（d）に，着色液の軌 跡を示す。（d）に上机ば，真空脱水に上る脱水効果は 中層までしか期待できないことが予测される。これは, 真空脱水によるコンクリート内部の間隙水压を測定した 既往の研究結果 ${ }^{11}$ 之同様の傾向である。

このように, コンクリート中の自由水は, 真空脱水に より, 加圧脱水時とほぼ同様の挙動を示すといえる。

\section{3 模式的に表した自由水の移動状況}

図-9 は, 実験結果汃ら自由水の移動状況を整理して, 模式的に表したあのである。(a)，（b）上（c)，（d）と 


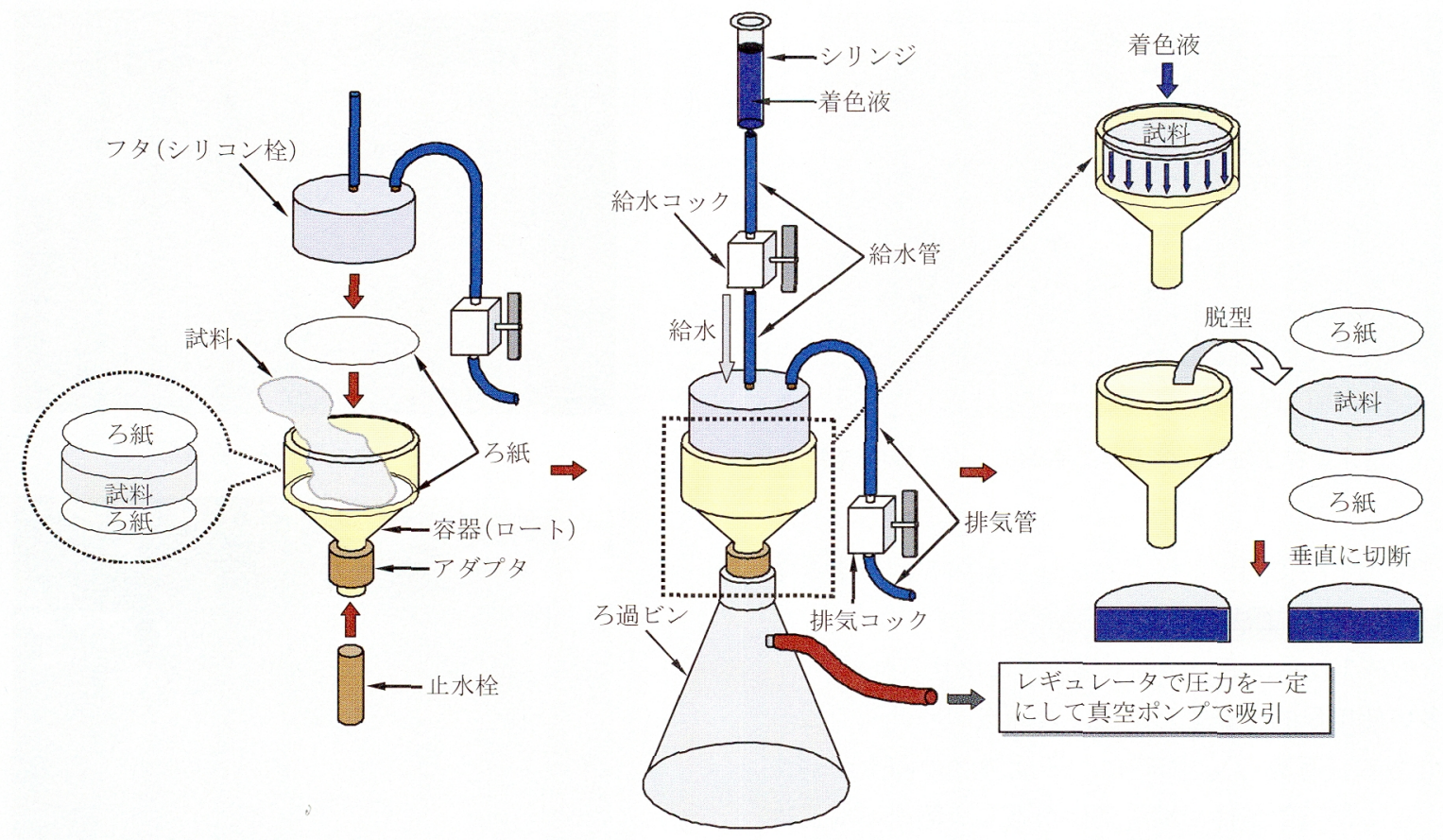

図-10 フレッシュモルタルの透水試験装置15)

の比較から分加るように, 透水や脱水に上る自由水の挙 動は，ブリーディングによる自由水の挙動之は明らかに 異なる。透水型枠工法では（c）に示すように，透水面 近傍の自由水は，透水面に向加って横方向や下方に移動 している。これは, 既往の研究モデル122 とは若干異なる 傾向であるが，本実験では，固体粒子の充てん密度や模 擬水の粘度を比較的小さな条件としているので，極端な 透水による自由水の移動状況を観察した結果によるもの 上考元ら机る。しかし，透水面のごく近傍にある自由水 の挙動は, 本実験結果に近いむのと推察される。

加圧脱水工法之真空脱水工法に上万自由水の移動状況 は，(d）に示すように同様の傾向を示している。加生 脱水工法による自由水の移動状況を調べた二次元可視化 実験に関しては，3.2（3）で既往の研究結果"1) と異な ることを述べた。しかし，真空脱水工法関しては，既 往の解析結果 ${ }^{13}$ 上ほぼ同様の挙動である。

4. 自由水の挙動に関する定量的評価

土質工学の分野では，土中の間隙を移動する水の性質 を知る上で，上の透水試験により透水係数が求めら机て いる。フレッシュモルタルやコンクリートむ同様に，そ の透水係数を知り得机ば, 自由水の挙動を定量的に評価 する手がかりとなる。土の透水試験方法は, Darcy の 法則に基づく透水係数を求为る試験として, 従来から標 準化されている。しかし，フレッシュモルタルやコンク リートの透水試験には標準化された方法はなく, 実験的 に検討された例はほとんどみられない尚。そこで，水頭 差に代えて真空生（吸引生）を利用したフレッシュモル タルの透水試験方法を考案（図-10）し，透水係数によ り自由水の挙動を定量的に評価することを試みた

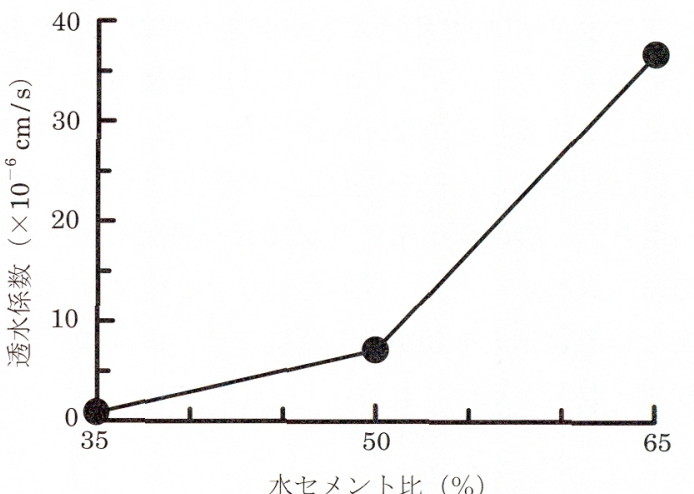

図-11 フレッシュモルタルの透水係数と水セメント比の関係 ${ }^{15}$

一例として図-11に，透水係数之水セメント比の関係 在示す。図に示すように, 透水係数の值は, 水セメント 比の増大に伴い大きくなる傾向を示している。とくに水 セメント比が $65 \%$ では，著しく大きな值を示している。 このような傾向は 2.2 節で報告した，フレッシュモル夕 ル中の自由水（着色液）の上昇距離と水セメント比との 関係（図-6）や，ブリーディング量との関係 (図-7）亡 同様の傾向である。したがって，本実験で得られたフレッ シュモルタルの透水係数は，ブリーディングによる自由 水の上昇挙動之密接な関係があり，水セメント比やブリー ディング量と相関のある值を示したといえる。

フレッシュモルタルやコンクリートの透水係数に関す る研究は，まだ緒についたところであるが，圧密圧力や 間隙水压分布考慮すれば，自由水の挙動についても定 量的な評価ができるものと考えられる。

5 . 透水・脱水工法の適用事例

透水・脱水工法の適用事例として，透水型枠工法抢上 


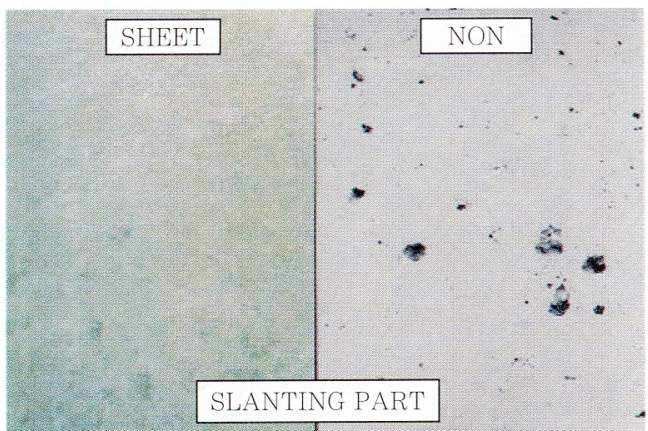

写真-7 透水型枠工法に関する施工事例 (表面美観の改善) ${ }^{8}$

び真空脱水工法に関する代表的な施工事例を紹介する

\section{1 透水型枠工法}

透水型枠工法は, 既に幾例む実施工に供せられており, 最も多い使用目的は充てん不良, 表面気泡の低減対策の ようである（写真-7）。同時に，表面強度の向上が期待 でき，上くに気象条件や環境条件が㛜しい箇所の構造物 では耐久性の向上を目的として採用されている。

\section{2 真空脱水工法}

真空脱水工法は 60 年ほど前に開発された工法であり, すでに幾例も実施工が行われている（写真-8）。しかし， 業界に広く普及したのは，車路に使用されている輪型防 滑工法だけである。真空脱水工法の改質効果は認知され つつあり，一般の建築床スラブにも一部採用されている ものの, 汎用レベルには達していない。床スラブには久 かせない改質効果を効率良く享受できるように，工法の 再検討・改善が期待される。

6. まとめ

本稿では，ブリーディングによる自由水の挙動と，透 水型枠工法, 加圧脱水工法, および真空脱水工法などよ いった自由水の制御工法の脱水メカニズムを可視化実験 結果を中心に概説した。

今後は，フレッシュモルタルやコンクリートの透水係 数について詳細に検討し, 自由水の挙動を定量的に把握 していきたいと考えている。また，圧密圧力や間隙水压 の分布を考慮し，透水や脱水による自由水の挙動につい ても定量的に評価できればと考えている。

謝 辞 本研究の一部は, (社)日本コンクリート工学 協会「透水・脱水によるコンクリートの品質改善方法研 究委員会」(平成 $14 \sim 15$ 年度, 委員長：畑中重光）の活 動の一環として行われたものである。研究を実施するに あたり，委員の放には貴重なご助言をいただいた。こ こに付記して謝意を表します。

\section{参 考 文 献}

1) 辻 正哲・坂井秀紀：ブリージング発生機構に関する基礎的研究， セメント技術年報，No.37，pp.229〜232，1983

2）加賀秀治：高性能 $\mathrm{AE}$ 減水剂の使用量の変動がコンクリートの品

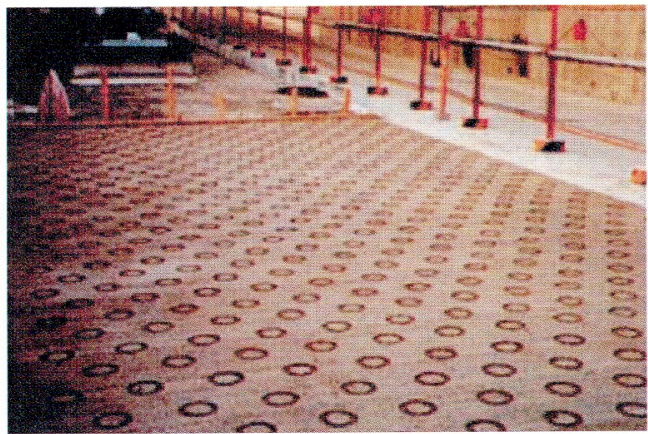

（a）スロープ車路への適用

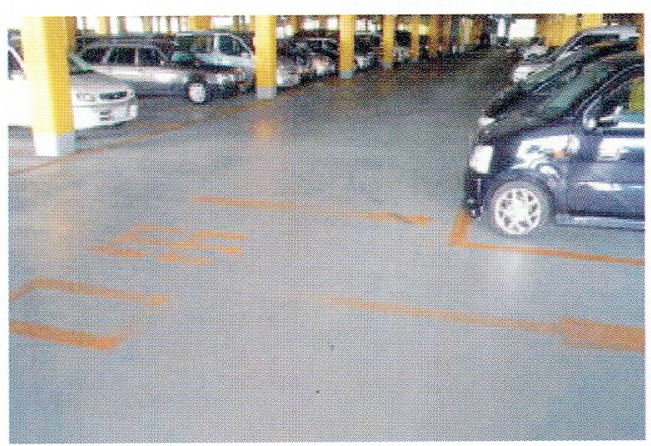

(b) 駐車場床への適用

\section{写直-8 真空脱水工法に関する施工事例 8}

質に及ぼ寸影響, 日本建築学会大会 (北陸) 学術講演梗概集, A, pp.569 570, 1992.8

3）小野博宣・伊藤知幸：フレッシュモルタルのブリージング特性 セメント・コンクリート論文集，No.51，pp.424〜429，1997

4）犬飼利嗣・畑中重光・三島直生・金子林爾：視覚的評価方法にも とづくモルタル中の自由水のブリーディング挙動に関する実験的 研究, 日本建築学会構造系論文集, 第 590 号, pp.1 7, 2005.4

5）加賀秀治：フレッシュコンクリートのブリージング機構に関する 研究, 日本建築学会大会 (関東) 学術講演梗概集, A, pp.1191 $\sim 1192,1993.9$

6）加藤佳孝・魚本健人：セメントペーストの凝集構造がブリーディ ングに与元る影響，土木学会論文集，No.592/V-39，pp.121〜 129. 1998.5

7）太田 顕・名和豊春・大沼博志：セメント粒子の凝集構造とセメ ントペーストの流動性の関係，コンクリート工学年次論文集， Vol.23, No.2, pp.271 276, 2001

8）日本コンクリート工学協会：透水・脱水によるコンクリートの品 質改善方法研究委員会報告書, 日本コンクリート工学協会, 2004.9

9）犬飼利品司・畑中重光・三島直生・張 珢秀: 可視化手法に基づく 透水・脱水コンクリート中の自由水の挙動評価に関する実験的研 究，コンクリート工学年次論文集，Vol.27, No.1, pp.595〜600, 2005.6

10）犬飼利勋・生丸浩至・山口昇三・松山高之・三島直生・畑中重光： 視覚的評価方法老用いて測定した透水・脱水によるコンクリート 中の自由水の举動，透水・脱水によるコンクリートの品質改善に 関するシンポジウム論文集，pp.231〜236，2004.9

11）服部宏已・畑中重光・三島直生・坂本英輔：圧密理論老適用した 真空脱水工法の脱水メカニズムに関する基濋的研究, 日本建築学 会構造系論文集，第585号，pp.7 13，2004. 11

12）伊藤康司・丸山久一・清水敬二・憍本親典：フレッシュコンクリー 卜の脱水機構に関する解析的研究, コンクリート工学年次論文集, Vol. 12, No.1, pp.263 268, 1990.7

13）平川博也・小野貴史・大下英吉：真空脱水処理工法に伴うコンク リート内部の水分移動性状に関する実験的研究, コンクリート工 学年次論文集, Vol. 26, No.1, pp.1359 1364，2004.7

14）平田隆祥・竹田宣典・十河茂幸：石灰石粉を用いたコンクリート のブリージング水の移動機構之強度分布について，コンクリート 工学年次論文報告集，Vol. 15，No.1，pp.501 506, 1993.5

15）犬飼利嗣・三島直生・坂本英輔・畑中重光：フレッシュモルタル の透水係数に関する実験的研究，コンクリート工学年次論文集, Vol. 28, No.1, pp.1109 1114, 2006.7 